\title{
DEVELOPMENT OF THE PERFORMANCE CONFIRMATION PROGRAM AT YUCCA MOUNTAIN, NEVADA
}

March 14, 2006

Gary D. LeCain, USGS

gdlecain@,usgs.gov

Richard Snell, BSC

richard_snell@ymp.gov
Deborah Barr, DOE

deborah_barr@ymp.gov

Stephen W. Goodin, BSC

stephen_goodin@ymp.gov
Douglas Weaver, LANL douglas_weaver@lanl.gov

Francis D. Hansen, SNL fdhanse@sandia.gov

\section{ABSTRACT}

The Yucca Mountain Performance Confirmation program consists of tests, monitoring activities, experiments, and analyses to evaluate the adequacy of assumptions, data, and analyses that form the basis of the conceptual and numerical models of flow and transport associated with a proposed radioactive waste repository at Yucca Mountain, Nevada. The Performance Confirmation program uses an eight-stage risk-informed, performance-based approach. Selection of the Performance Confirmation activities (a parameter and a test method) for inclusion in the Performance Confirmation program was done using a risk-informed performance-based decision analysis. The result of this analysis and review was a Performance Confirmation base portfolio that consists of 20 activities. The 20 Performance Confirmation activities include geologic, hydrologic, and construction/engineering testing. Several of the activities were initiated during site characterization and are ongoing. Others activities will commence during construction and/or post emplacement and will continue until repository closure.

\section{INTRODUCTION}

The Yucca Mountain Project (YMP) is a scientific study by the U.S. Department of Energy (DOE) to evaluate the potential for geologic disposal of high-level radioactive waste in an unsaturated-zone desert environment. The Performance Confirmation (PC) program consists of tests, monitoring activities, experiments, and analyses to evaluate the adequacy of assumptions, data, and analysis that form the basis of the conceptual and numerical models of flow and transport at Yucca Mountain. The PC program is designed to test whether: 1) the actual subsurface conditions encountered are as anticipated, 2) any changes in these conditions during construction and waste emplacement are within expected limits, and 3) the natural and engineered systems are functioning as intended. 
Regulatory requirements for the PC program are specified in the United States Code of Federal Regulations 10 CFR 63 , Subpart F (NRC, 2005). Guidance for the program also is provided in the Yucca Mountain Review Plan (NRC 2003). The purpose and objectives of the PC program, as stated in regulation 10 CFR 63.102(m) is that:

"a performance confirmation program be conducted to evaluate the adequacy of assumptions, data, and analyses that led to the findings that permitted construction of the repository and subsequent emplacement of the wastes. Key geotechnical and design parameters, including any interactions between natural and engineered systems and components, will be monitored throughout site characterization, construction, emplacement, and operation to identify any significant changes in the conditions assumed in the license application that may affect compliance with the performance objectives specified at 63.113(b) and (c)."

The repository system is composed of natural and engineered barriers that have been characterized and designed to work together to prevent or reduce the release rate of radionuclides from a proposed repository at Yucca Mountain. The natural barriers consist of: 1) Surface Topography, Soils and Bedrock, 2) Unsaturated Zone above the repository, 3) Unsaturated Zone below the repository, and 4) Saturated Zone between the repository and the accessible environment. The engineered barriers consist of: 1) Drip Shield, 2) Waste Package, 3) Waste Form, 4) Cladding, and 5) the Drift Invert. When the natural and engineered barriers systems are considered as a unit, the possibility is reduced that uncertainties associated with any one parameter might result in conditions that could lead to exceeding the postclosure performance objectives for individual (human) and groundwater protection or result in conditions that would preclude retrieval of the waste. The PC program goal is to improve the confidence and accuracy in our understanding of these barriers and their subsystem components, as well as the overall system sensitivity to particular features. The PC program is designed to confirm the design and model parameters and consequently the basis for predictions of long-term performance and the retrievability option (BSC, 2004a).

The PC program uses an eight-stage, risk-informed, performance-based approach. The eight stages of the approach are:

1. Select PC parameters and test methods

2. Predict performance and establish a baseline

3. Establish bounds and tolerances for key parameters

4. Establish test completion criteria and variance guidelines

5. Plan activities, and construct and install the PC program 
6. Monitor, test, and collect data

7. Analyze and evaluate data

8. Recommend corrective action in the case of variance.

Stage 1 has been completed. The PC program is presently addressing stages 2, 3 and 4; this primarily consists of preparing the Technical Work Plans (TWP) for the PC activities, and includes defining the expected parameter baselines and tolerances.

Advances in technology and scientific understanding at Yucca Mountain will occur over the life of this program. A successful PC program is flexible, with a process to reevaluate, reexamine, and modify PC activities as the state of understanding changes. New tests may be needed, or may become possible with new technology, and tests that are no longer providing useful information may be discontinued. The PC program is designed to allow the DOE to continually update and improve the PC program with the ultimate goal of building a body of evidence that will improve the safety-related knowledge base.

\section{REGULATORY REQUIREMENTS}

To meet the regulatory requirements of 10 CFR Part 63, the PC program is focused on those activities necessary to identify and evaluate significant changes in the conditions assumed in the license application that may affect compliance with the specified performance objectives for individual protection, groundwater protection, and retrievability. The capabilities of barriers identified as important to waste isolation are key to demonstrating compliance with the postclosure performance objectives for individual and groundwater protection. Barriers prevent or substantially reduce the rate of movement of water or radionuclides from the repository to the accessible environment, or prevent the release or substantially reduce the release rate of radionuclides from the waste. Identification of the barriers important to waste isolation and of the processes and conditions that may significantly affect the capabilities of these barriers provides a risk-informed, performance-based system for determining the scope of the postclosure aspects of the PC program. Monitoring subsurface conditions and testing to confirm geotechnical and design assumptions addresses compliance with the preclosure aspect of PC to ensure the preservation of the retrievability option (BSC, 2004c). 
In summary, the $\mathrm{PC}$ program must:

- Confirm that subsurface conditions, geotechnical and design parameters are as anticipated and that changes to these parameters are within limits assumed in the License Application,

- Confirm that the waste retrieval option is preserved,

- Evaluate information used to assess whether natural and engineered barriers function as intended,

- Evaluate effectiveness of design features intended to perform a postclosure function during repository operation and development,

- Monitor waste package condition.

The PC program began during site characterization and will continue until permanent closure of the repository (10 CFR 63.131(b)). Relevant site characterization information is incorporated into the baseline for implementation of PC during repository construction and operation. A variety of testing and monitoring is anticipated as part of repository development and operation. Although the primary focus of the PC program is on postclosure performance of the repository, the PC program also includes activities to address the preservation of the ability to retrieve waste, however, operational and administrative controls of processes like materials qualification, waste acceptance, waste package testing and handling are not included in the PC program.

\section{RISK-INFORMED PERFORMANCE-BASED DECISION ANALYSIS AND PORTFOLIO DEVELOPMENT}

As stated in the Introduction, the evaluation of the potential PC activities for possible inclusion in the PC program used a risk-informed performance-based decision analysis. The term risk-informed refers to an evaluation of the probability of an event multiplied by the consequences of that event, and performance-based refers to the license application performance assessment analysis. The decision analysis approach: 1) accounts for the fact that there are multiple and potentially 
competing objectives for the PC program, 2) incorporates information from project personnel with different areas of expertise relevant to the selection of activities, and 3) provides a traceable and defensible logic for the PC activities selection.

The risk-informed performance-based evaluation method is based on multi-attribute utility analysis (Keeney and Raiffa 1976). The approach recognizes both value and technical judgments. Value judgments are management decisions about what is important; defining the objectives and criteria against which each of the activities are to be evaluated and specifying the relative importance of each criterion. The value judgments were provided by the Performance Assessment Project Management Team. Technical judgments are about which activities best meet the criteria defined by management. In this analysis, technical judgments included the definition of the parameter and the proposed data acquisition method, and how well each activity (parameter and analysis method) meets the criteria defined by the Performance Assessment Project Management Team. The technical evaluations were provided by YMP scientists.

Stage 1 of the analysis was conducted in three phases. In the first phase, YMP scientists identified candidate PC activities (combination of a parameter and a test method) for possible inclusion in the PC program. The activities were then evaluated based on their potential impact to performance and test feasibility. Approximately 360 activities were identified. Parameters varied significantly, ranging from specific total system performance assessment (TSPA) model input parameters, such as sorption coefficients $(\mathrm{Kd})$, to summary-level parameters more directly related to the confirmation of modeling results, such as seismic parameters, strong ground motions, and fault displacement. The first step in evaluating the activities was to define a set of criteria that specify the attributes of a "good" PC activity. To define these evaluation criteria, a team of about 25 managers and technical investigators convened a one-day workshop to discuss potential evaluation criteria. The team defined three criteria that were used to evaluate the activities:

1. Sensitivity of total system performance and barrier capability to the parameter

2. Confidence in the current representation of the parameter

3. Accuracy of the proposed methodology to measure the parameter

The cost of measuring the parameter also was identified as an applicable criterion, but was developed separately from the three criteria that contribute to the activity's benefit, or "utility"(BSC, 2003). 
A highly rated activity is one where the barrier is highly sensitive to the parameter, where the measurement methodology is very accurate, and for which the project has low confidence in the current representation of that parameter. In contrast, an activity where the barrier is insensitive, where measurement is difficult or inaccurate, and for which the project has high confidence in the current representation of that parameter would receive a low rating.

A detailed set of questions were developed to assist the scientific staff to specify how well each proposed activity meets the defined evaluation criteria. The technical judgments for each candidate activity are documented in the Performance Confirmation Plan Rev 02, Appendix B (BSC, 2003). Use of YMP scientists ensured that the most up-to-date technical knowledge was included in the evaluation. In addition, a small "core team" of YMP technical experts evaluated all the proposed activities to provide a consistency check on the evaluations from the individual scientists. Substantial differences in evaluations were discussed, and differences of opinion were resolved either by mutual agreement or by elevation to the manager of the Performance Assessment Strategy and Scope Subproject.

The second phase consisted of organization of the activities into "portfolios" (sets of activities), any one of which could form the basis for the PC program. Some portfolios emphasized the relative importance of the technical activities, others emphasized cost, and others placed focus on types of activities (for example, in situ or laboratory). The portfolios were evaluated and compared on the basis of a number of portfolio-level criteria. Eleven portfolios were developed on the basis of estimated utility and cost of each activity. All of the alternative portfolios developed met the general requirements with varying degrees of robustness. Details of the organization of the portfolios are in the Performance Confirmation Plan Rev 2, Appendix B (BSC, 2003).

In the third phase, project managers reviewed the 11 portfolios, selected a portfolio to serve as the base for the PC program, and directed modifications to increase the robustness of the selected portfolio (BSC, 2003). The portfolios were presented to management, along with indexes to the regulatory requirements and costs assessments. Based on the evaluations of the 11 candidate portfolios, the Manager of Projects and the Project Oversight Board selected a cost-effectiveness threshold portfolio, with some modifications, as the base for the PC program. The portfolio modifications were based on a review by the PC Project Team, and several additional activities were added to increase the regulatory requirements robustness. The Manager of Projects and advisors then reviewed every activity in the proposed portfolio, including the proposed additions, and made additional modifications (BSC, 2003). 


\section{SELECTION OF PERFORMANCE CONFIRMATION ACTIVITIES}

Following the selection of the PC program base portfolio, an additional series of management and key technical representative reviews were conducted to refine the list of activities and to bring the list of activities into closer alignment with regulatory requirements and plans for the License Application (BSC, 2004b). This final review also included a change in how the barriers at Yucca Mountain were organized. In the new grouping the repository system is composed of three barriers, two natural barriers, and one engineered barrier. The three barriers are:

1) Upper Natural Barrier

i. Surface topography, soils and bedrock

ii. Unsaturated zone above the repository (includes the repository)

2) Engineered Barrier System

i. Drip shield

ii. Waste package

iii. Waste form

iv. Cladding

v. Drift invert

3) Lower Natural Barrier

i. Unsaturated zone below the repository

ii. Saturated zone between the repository and accessible environment

The final management and key technical representative review consolidated related activities where appropriate. Activities that did not strongly support regulatory compliance or the assessment of repository performance were removed from the program (although these activities may be considered for other testing programs), and a few activities were added to increase the regulatory robustness. The result of these reviews was the current list of 20 activities. Table 1 presents the 20 selected PC program activities, a short activity description, and the barrier associated with the activity. 
Table 1. Testing and monitoring activities to be included in the PC program. (* Activity that began during Site Characterization.)

\begin{tabular}{|c|c|c|}
\hline ACTIVITY TITLE & ACTIVITY DESCRIPTION & BARRIER or PROCESS \\
\hline $\begin{array}{l}\text { *Precipitation } \\
\text { monitoring }\end{array}$ & Monitoring of precipitation and composition analysis. & Upper Natural Barrier \\
\hline $\begin{array}{l}\text { *Seepage } \\
\text { monitoring }\end{array}$ & $\begin{array}{l}\text { Seepage monitoring and laboratory analysis of water } \\
\text { samples (from bulkheaded alcoves on the intake side } \\
\text { of the repository and in thermally accelerated drifts). }\end{array}$ & Upper Natural Barrier \\
\hline $\begin{array}{l}\text { *Subsurface water } \\
\text { and rock testing }\end{array}$ & $\begin{array}{l}\text { Laboratory analysis of chloride mass balance and } \\
\text { isotope chemistry based on samples taken at selected } \\
\text { locations of the underground facility. }\end{array}$ & $\begin{array}{l}\text { Upper and Lower } \\
\text { Natural Barriers }\end{array}$ \\
\hline $\begin{array}{l}\text { *Unsaturated zone } \\
\text { testing }\end{array}$ & $\begin{array}{l}\text { Testing of transport properties and field sorptive } \\
\text { properties of the crystal-poor member of the Topopah } \\
\text { Spring Tuff, in an ambient seepage alcove or a drift. }\end{array}$ & $\begin{array}{l}\text { Upper and Lower } \\
\text { Natural Barriers }\end{array}$ \\
\hline $\begin{array}{l}\text { *Saturated zone } \\
\text { monitoring }\end{array}$ & $\begin{array}{l}\text { Monitoring of water level and hydrochemical } \\
\text { sampling of the saturated zone upgradient, beneath } \\
\text { and downgradient of Yucca Mountain. }\end{array}$ & Lower Natural Barrier \\
\hline $\begin{array}{l}\text { Saturated zone fault } \\
\text { hydrology testing }\end{array}$ & $\begin{array}{l}\text { Hydraulic and tracer testing of fault zone hydrologic } \\
\text { characteristics, including anisotropy, in the saturated } \\
\text { zone. }\end{array}$ & Lower Natural Barrier \\
\hline $\begin{array}{l}{ }^{*} \text { Saturated zone } \\
\text { alluvium testing }\end{array}$ & $\begin{array}{l}\text { Tracer testing at the Alluvial Test Complex using } \\
\text { multiple boreholes measuring parameters in the } \\
\text { alluvium. }\end{array}$ & Lower Natural Barrier \\
\hline $\begin{array}{l}\text { Periodic Drift } \\
\text { inspection }\end{array}$ & $\begin{array}{l}\text { Regular inspection of nonemplacement drifts and } \\
\text { periodic inspection of emplacement drifts, thermally } \\
\text { accelerated drifts, and other underground openings } \\
\text { using remote measurement techniques, as appropriate. }\end{array}$ & $\begin{array}{l}\text { Engineered Barrier System, } \\
\text { Retrievability }\end{array}$ \\
\hline $\begin{array}{l}\text { Thermally } \\
\text { accelerated drift } \\
\text { near-field } \\
\text { monitoring }\end{array}$ & $\begin{array}{l}\text { Monitoring of near-field coupled processes (thermal- } \\
\text { hydrologic-mechanical-chemical) properties and } \\
\text { parameters associated with the thermally accelerated } \\
\text { drifts. }\end{array}$ & $\begin{array}{l}\text { Upper and Lower } \\
\text { Natural Barriers }\end{array}$ \\
\hline $\begin{array}{l}\text { Dust buildup } \\
\text { monitoring }\end{array}$ & $\begin{array}{l}\text { Monitoring and laboratory testing of quantity and } \\
\text { composition of dust on engineered barrier surfaces. }\end{array}$ & Engineered Barrier System \\
\hline $\begin{array}{l}\text { Thermally } \\
\text { accelerated drift in- } \\
\text { drift environment } \\
\text { monitoring }\end{array}$ & $\begin{array}{l}\text { Monitoring and laboratory testing of gas composition; } \\
\text { water quantities, composition, and ionic } \\
\text { characteristics (including thin films); microbial types } \\
\text { and amounts; and radiation and radiolysis within a } \\
\text { thermally accelerated drift. }\end{array}$ & Engineered Barrier System \\
\hline $\begin{array}{l}\text { *Subsurface } \\
\text { mapping }\end{array}$ & $\begin{array}{l}\text { Mapping of fractures, faults, stratigraphic contacts, } \\
\text { and lithophysal characteristics. }\end{array}$ & $\begin{array}{l}\text { Upper and Lower } \\
\text { Natural Barriers }\end{array}$ \\
\hline $\begin{array}{l}\text { *Seismicity } \\
\text { monitoring }\end{array}$ & $\begin{array}{l}\text { Monitoring regional seismic activity. Observation of } \\
\text { subsurface and surface (large magnitude) fault } \\
\text { displacement after significant local or regional } \\
\text { seismic events. }\end{array}$ & Disruptive Event, Retrievability \\
\hline $\begin{array}{l}{ }^{*} \text { Construction } \\
\text { effects monitoring }\end{array}$ & $\begin{array}{l}\text { Monitoring construction deformation to confirm } \\
\text { mechanical properties. }\end{array}$ & $\begin{array}{c}\text { Upper Natural Barrier, } \\
\text { Retrievability }\end{array}$ \\
\hline
\end{tabular}




\begin{tabular}{|l|l|c|}
\hline $\begin{array}{l}\text { Thermally } \\
\text { accelerated drift } \\
\text { thermal-mechanical } \\
\text { monitoring }\end{array}$ & $\begin{array}{l}\text { Monitoring drift and invert shape and integrity in a } \\
\text { thermally accelerated drift. }\end{array}$ & $\begin{array}{c}\text { Engineered Barrier System, } \\
\text { Retrievability }\end{array}$ \\
\hline Seal testing & $\begin{array}{l}\text { Laboratory testing of effectiveness of borehole seals } \\
\text { followed by field-testing of effectiveness of ramp and } \\
\text { shaft seals. Testing, as appropriate, to evaluate the } \\
\text { effectiveness of backfill placement. }\end{array}$ & $\begin{array}{c}\text { Engineered Barrier System, } \\
\text { Upper Natural Barrier }\end{array}$ \\
\hline $\begin{array}{l}\text { Waste package } \\
\text { monitoring }\end{array}$ & $\begin{array}{l}\text { Remote monitoring for evidence of external corrosion } \\
\text { of the waste package. }\end{array}$ & Engineered Barrier System \\
\hline *Corrosion testing & $\begin{array}{l}\text { Corrosion testing in the laboratory of waste package } \\
\text { and drip shield samples in the range of representative } \\
\text { repository thermal and chemical environments. } \\
\text { Includes laboratory testing of general corrosion, phase } \\
\text { transformations of Alloy 22; and localized corrosion. }\end{array}$ & Engineered Barrier System \\
\hline $\begin{array}{l}\text { Corrosion testing of } \\
\text { thermally } \\
\text { accelerated drift } \\
\text { samples }\end{array}$ & $\begin{array}{l}\text { Corrosion testing in the laboratory of waste package } \\
\text { and drip shield samples exposed to conditions in the } \\
\text { thermally accelerated drifts. Includes corrosion model } \\
\text { applicability and laboratory testing of general } \\
\text { corrosion, phase transformations of Alloy 22; and } \\
\text { localized corrosion. }\end{array}$ & Engineered Barrier System \\
\hline *Waste form testing & $\begin{array}{l}\text { Waste form testing (including waste package coupled } \\
\text { effects) in the laboratory under internal waste package } \\
\text { conditions. }\end{array}$ & Engineered Barrier System \\
\hline
\end{tabular}

Because the development of the PC program and selection of the PC activities were conducted prior to completion of the Total System Performance Assessment for the license application (TSPA-LA) an assessment of the relevance of the PC program to the draft TSPA-LA was conducted (Watson 2004). The assessment affirmed that 17 of the $20 \mathrm{PC}$ activities are the most directly relevant to postclosure performance assessment of the natural and engineered barriers and ranged from medium to high importance to the TSPA-LA. The three activities not directly relevant to postclosure performance (Construction Effects Monitoring, Drift Inspection, and Thermally Accelerated Drift Thermal-Mechanical Monitoring) are related to the assessment of conditions that support the retrievability option and may provide information to assess the general framework for model development.

In addition, the assessment indicated that the igneous intrusion modeling case required additional evaluation for the relevant subsystem features and processes that are important in modeling total system performance, and identified possible enhancements or clarifications of the scope of PC activities that may have merit in supporting the technical basis for the current TSPA-LA (Watson 2004). These enhancements/clarifications include: 
- Sorption of some radionuclides on stationary phases (attachment to non-mobile materials)

- In-package radionuclide solubility

- In-package diffusion characteristics.

The review concluded that no new PC activities were required, however, clarifications to the purpose and modifications to the anticipated methodology for waste form testing now better confirm igneous scenario assumptions. These clarifications of scope of this existing activity support the technical basis for PC for the assessment of total system performance for the igneous intrusion scenario (BSC, 2004c).

\section{IMPLEMENTATION AND SCHEDULE}

Implementation of the PC program and the associated PC activities will be documented and controlled using PC Technical Work Plans (TWP). The TWPs will describe the methodologies for monitoring, testing, and collection of data, and will describe the methods for analyzing and evaluating the data. The TWPs will establish expected ranges and tolerances for parameters, test completion criteria, and criteria for implementation of the PC activities. The TWPs will also address variance conditions (conditions/data outside the expected ranges) and required actions. Current Science Investigation Test Plans and Work Plans governing ongoing activities that will be incorporated into the PC program will be transitioned to TWPs. Development of the TWPs will be the responsibility of the PC Department. Subject matter experts will review each of the PC activities in the context of the TSPA and sensitivity studies to identify those parameter value ranges and distributions important to PC. The TWPs will include reviews to ensure that planned testing does not adversely affect the ability of the repository to meet the performance objectives and is consistent with safe operation of a geologic repository. The PC field and laboratory work will be controlled by fieldwork packages, technical procedures, scientific notebooks, test work authorizations, and work orders (BSC, 2004c). As previously mentioned, several of the PC activities were initiated during site characterization and the PC program will continue during repository construction and through operational emplacement of waste concluding when repository closure is licensed.

Figure 1 presents the implementation schedule for the 20 PC activities. These 20 activities fall into three groups:

- Preconstruction (continuation of activities initiated during site characterization)

- Construction (activities during construction and waste emplacement) 
- Operation/monitoring (post-waste emplacement until repository closure).

Activities initiated during site characterization have a greater level of planning and scheduling detail than those in later phases of the Project. At present TWPs are being prepared for Precipitation Monitoring and Construction Effects Monitoring. Additional schedule details for ongoing activities are contained in their existing scientific investigation test plans or technical work plans and will be included in future the TWPs. This schedule assumes a construction start date of 2007 and an operation start date of 2010 followed by a 100 -year operation/monitoring period.

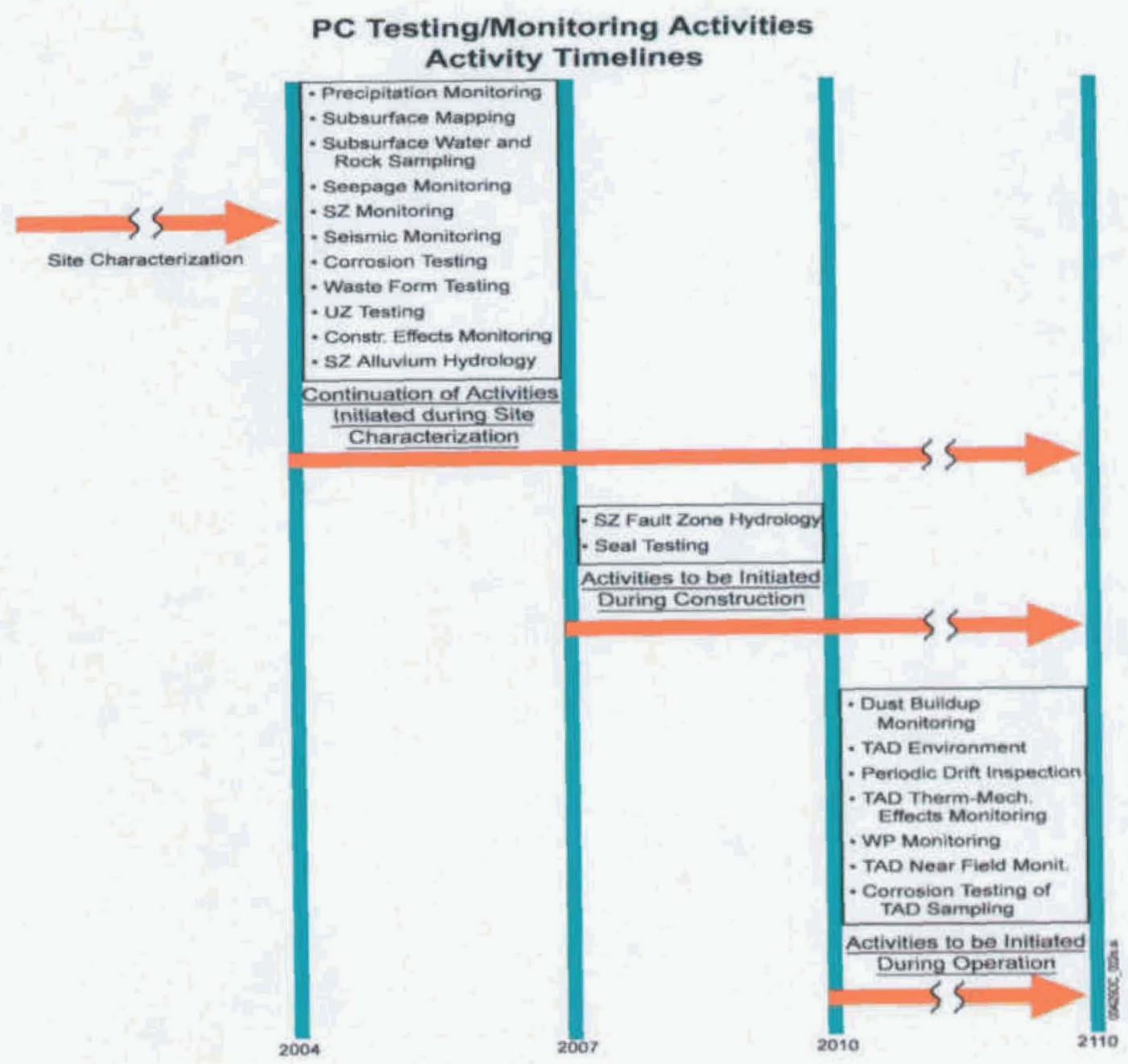

Figure 1. Schedule for PC activities. [WP: Waste Package, TAD: Thermally Accelerated Drift] (from Figure 6-1, Performance Confirmation Plan Rev 4 (BSC, 2004b) 


\section{REFERENCES}

BSC, 2003, Performance Confirmation Plan TDR-PCS-SE-000001 Rev. 2: Las Vegas, Nevada, Bechtel SAIC Company, DOC.20030703.0001.

BSC, 2004a, Performance Confirmation Plan TDR-PCS-SE-000001 Rev. 3: Las Vegas, Nevada, Bechtel SAIC Company, DOC.20040412.0008.

BSC, 2004b, Performance Confirmation Plan TDR-PCS-SE-000001 Rev. 4: Las Vegas, Nevada, Bechtel SAIC Company, DOC.20040825.0002.

BSC, 2004c, Performance Confirmation Plan TDR-PCS-SE-000001 Rev. 5: Las Vegas, Nevada, Bechtel SAIC Company, DOC.20041122.0002.

Keeney, R.L., and Raiffa, H., 1976, Decisions with Multiple Objectives: Preferences and Value Tradeoffs: New York, New York, John Wiley \& Sons, TIC: 208907.

Watson, W.W., 2004, Meeting Notes: Assessment of the Proposed Performance Confirmation Program Relevance to TSPALA: Interoffice Memorandum dated October 27, 2004, MOL: 20041027.0247.

NRC, 2003, Yucca Mountain Review Plan NUREG-1804, Rev. 2: Washington D.C., U.S. Nuclear Regulatory Commission, TIC 254568.

NRC, 2005, 10 CFR 63--Disposal of High-Level Radioactive Wastes in a Geologic Repository at Yucca Mountain, Nevada. Readily available. 